\title{
POLICING THE POLICE IN THE UNITED KINGDOM
}

\section{INTRODUCTION}

Since the late 1950s, the need for an effective system for dealing with complaints against the police has been a "live issue” in the UK (Maguire 1991: 177). Unlike some countries, where responsibility for dealing with complaints against the police rests with the national ombudsman as part of the general remit over the way public bodies deal with citizens, the police in the UK are not within the remit of the Parliamentary or local authority ombudsmen. In the UK, the mechanisms that exist for dealing with police complaints have grown up independently of the ombudsmen systems established for other public sector services. Moreover, these specialised mechanisms do not conform to one single model, with the result that the police complaints systems in England and Wales, Northern Ireland and Scotland have different features and different levels of external oversight.

In all three jurisdictions, recent years have seen a period of change. A new system for police complaints has recently been initiated in England and Wales, with the introduction of the Independent Police Complaints Commission in April 2004; Northern Ireland's Police Ombudsman, introduced in October 2000, is establishing itself as a high profile and effective office; and Scotland is in the process of considering proposals to change its system for investigating complaints against the police. It is within this context that this paper examines various models for police complaints systems, and reviews the three systems for dealing with complaints against the police within the UK.

\section{POLICE COMPLAINTS AND ACCOUNTABILITY}


In some ways complaints against the police are no different from other complaints by consumers of public services. Complaints are unresolved problems where redress is needed, and effective mechanisms for dealing with them are an essential aspect of the accountability of that service. However, accountability mechanisms have an added dimension for the police service, as the police are in a very different position to other providers of public services. They are the gatekeepers of the criminal justice system, and this role means that they have a range of powers and equipment to enable them to carry out their law enforcement function. For example, they have powers of arrest, they can deprive citizens of their liberty, and they can question and detain. They can impose upon personal and community freedom in a way that no other body of persons can. They have considerable coercive powers, and the way they exercise those powers involves a significant amount of discretion.

Police misconduct thus presents a particular threat to the rights and liberties of individual citizens. Moreover, it can also undermine the credibility of the criminal justice system, the effectiveness of policing, and the legitimacy of government (see Bayley 1995: 93). Tackling police misconduct is difficult because of the organisational culture of policing, where group loyalty militates against officers testifying against each other. Pressures on the police to secure convictions, particularly in high profile cases, also leads to ‘noble cause' corruption, where police officers, convinced of the guilt of suspects, "routinely” deviate from rules and regulations in order to secure convictions (Punch 2003: 187).

As a result of this, it is of major importance that there is some external control over police powers, and adequate systems of accountability.

\section{Accountability Mechanisms}


Within the UK, there is a tripartite system of control for the police: central government, local government and the police organisation itself. Central government control is exercised by ministers; local control is the function of police authorities, and the police side of the tripartite structure is exercised by the chief constable, pursuant to the concept of constabulary independence.

Like any citizen, individual police officers are subject to the criminal law, and can, of course, be prosecuted for crimes they may commit in the course of carrying out their duties. In all three jurisdictions, the function of prosecution of police officers remains with the public prosecutor's department, and is thus outside of the police organisation. There is, of course, a structural relationship between the police and the prosecuting authorities, and this "may give the impression, whatever the reality, of collusion” (Harrison and Cragg 1995: 113), and concerns have been expressed in England and Wales as to whether there are problems in relation to impartiality where a police officer is prosecuted (see Cunneen and Harrison 2001).

\section{Civil litigation}

As with other public services, individual citizens can pursue civil cases for damages where torts are committed by the police, for example for personal injury caused by a police officer. There is little statistical detail about this, but the evidence suggests that in England and Wales during the last quarter of a century there has been a significant increase in the number of actions for damages against the police (Smith 2003: 413; McLaughlin and Johansen 2002: 642). Published figures reveal that in 1998/99 there were 5961 civil claims and settlement awards totaling $£ 4.61$ million (HMIC 1999). In the following year, there were 5357 claims, and £6,898 million paid out (HMIC 2000). However, the figures are erratic, and it has been noted that there is a "dearth of 
quantitative data on police action” and a "paucity of qualitative research” (Smith 2003: 413).

Research that has been conducted has noted that the motive in suing the police is not chiefly financial, "but to bring facts to light, or to bring the police to book" (Ward 2002: 21). While financial compensation clearly plays a major role in offsetting claimants' frustration, the non-pecuniary aspects of civil procedure are also important. These include the openness of the procedure; the independence of the adjudication; the public vindication if successful; and the fact that claimants can proceed with a considerable degree of equality with the defendant (Smith 2003: 421). Even if damages are not awarded, claimants have the satisfaction of hearing police officers account for their conduct in court. This contrasts with police complaints systems where complainants neither hear officers answer for their conduct nor discover the action taken when misconduct is found (Smith 2004: 23).

Given that the chances of success in the civil courts in actions for damages are “dramatically higher” than pursuing a remedy through the complaints or criminal process (Ward 2002: 21), it is not surprising that many complainants do not bother with the formal complaints system, but turn instead to civil action (Smith 2004: 23; Reid 2002: 194). Litigation is proving a more effective way of achieving vindication for victims of police misconduct than complaints procedures. Moreover, civil actions can attract publicity and thus stimulate debate about police misconduct (Harrison and Cragg 1995: 9).

\section{Complaints procedures}

In addition to external remedies, individual police officers, like any other public servants, must be institutionally accountable for the way they do their job. 
Accountability is an essential prerequisite of public confidence in the police service, because, as already noted, police misconduct, if unfettered, can threaten the credibility of the criminal justice system and the effectiveness of the police. Confidence in the police is essential in a democratic society. A complaints process for police misconduct must therefore command the confidence of the public, in order to achieve public support for the police (see Goldsmith and Lewis 2000; Smith 2001). On the other hand, a negative experience with the police complaints system can have a wider negative effect on confidence in the whole police organisation since public perception of the effectiveness of the complaints system is an important component of the process of accountability (Strudwick 2003: 36). Police complaints systems have been described as one of the three pillars of accountability (Police Monitoring and Research Group 1987: 6), the other two being accountability to the law, and to the police authority. Thus, police complaints mechanisms are an important part of the process of democratic policing.

Complaints procedures are not the only means of formally addressing the issue of police accountability of course. As already noted, other accountability mechanisms include the traditional tripartite control structure, internal audit procedures, and the external Inspectorates, which together present a formidable level of scrutiny. However, it can be argued that it is complaints procedures which represent the "preeminent” mechanism for citizens to comment on a variety of police practices directly affecting their lives, providing a "grassroots” method and a "structured opportunity" for doing so (Goldsmith 1995: 110-111).

\section{MODELS OF POLICE COMPLAINTS SYSTEMS}


Internationally there are a number of models for police complaints systems. At one end of the spectrum, there is complete self-regulation, with the police conducting and regulating investigation into complaints, without any external oversight or input. At the opposite extreme, complaints against the police can be dealt with by a body entirely independent of the police, where the body has complete responsibility for the investigation of all complaints against the police. Within these two extremes, there is range of systems with varying degrees of internal and external investigation and different levels of civilian oversight, supervision and audit of the complaint handling function. Complaints bodies may be concerned with investigating the particulars of the incident complained about, or be limited to an investigation of the procedures involved in handling the complaint.

A complaints system may also have a number of functions, including maintaining internal discipline and providing information to management with which to make improvements, as well as satisfying complainants and gaining public confidence (Maguire and Corbett 1991). However, while the relationship between complaints and discipline is important, the complaint system should not simply serve as a preliminary stage for criminal or disciplinary proceeding for police officers, as this makes the complaint process "a poor relation of the discipline process" (Smith 2000: 4). On the contrary, it may be that "satisfying the complainant should be a prioritised objective of any police force” (Waters and Brown 2000:635). Thus, an effective complaints system must have adequate remedies, including making wrongdoers accountable for their behaviour, encouraging them to repair the harm they have caused, and satisfying the complainant that their case has been appropriately handled.

Prenzler and Ronken (2001), in their theoretical paper on the best form of control of police conduct, identify three models for police complaints systems: internal, civilian 
control and civilian review. Where complaints are dealt with internally, the only oversight provided is by the courts, in cases where police officers are prosecuted, and elected officials, in the form of police authorities. The internal model has received such “an extensive critique”, largely because of the "apparent pathological inability of police to objectively investigate their peers” (p. 157), that it is no longer seen as appropriate or acceptable. Thus, the only real issue to be addressed is what kind of civilian oversight model to adopt.

“Civilian review” involves an independent audit of internal investigations and disciplinary decisions. Within such a model, the police normally conduct investigations into complaints and determine what disciplinary actions should follow. The role of the external agency is to monitor the process. Noting that this is very much a compromise model, Prenzler and Ronken argue for the adoption of the civilian control model for police complaints, where there is genuinely independent investigation and adjudication of complaints (p. 166). In support of their argument, they draw on Scarman (1986: 182-183), who noted that "so long as the investigation of complaints remains in police hands”, there would continue to be criticisms of the system, and that only "the establishment of an independent service for the investigation of all complaints against the police” would silence this criticism.

The civilian control model need not weaken police responsibility for maintaining discipline, as police managers could still exercise their role in internal disciplinary matters (Prenzler and Ronken 2001: 169), and the police could also have prime responsibility for the mediation of complaints (p. 166). Nor do Prenzler and Ronken accept that it is only police officers who have the necessary competence in investigation skills and the capacity to penetrate the police world. Investigation is a generic skill that can be taught and developed in diverse contexts and penetration of 
the police world can be achieved by structural reform, including whistleblower protection legislation, mandatory reporting of misconduct and surveillance technology (p.168).

The advantage of the civilian control model is its independence, which is one of the most important features required in any system for investigating complaints if it is to inspire public confidence. The public has a deep suspicion of the way complaints against the police are handled, and thus complaints systems must not only be independent, but must also be perceived as such. In order for this to occur, there must be a "clear institutional separation of the person being investigated from the person doing the investigation” (Prenzler and Ronken 2001: 168).

\section{ENGLAND AND WALES: THE INDEPENDENT POLICE COMPLAINTS COMMISSION}

In England and Wales, the system for dealing with police complaints has traditionally followed the civilian review model. A new system has recently started, with the establishment of the Independent Police Complaints Commission (IPCC) in April 2004. Given that reform of police complaints procedures "is almost always preceded by some observable 'crisis’ of public legitimacy in the police” (Goldsmith 1988: 60), the context of police complaints in England and Wales will be summarised, before evaluating the new system.

\section{Context}

Before the 1960s, police forces dealt with complaints internally. However, these internal investigations were mistrusted (Lewis 1999: 29-30), and in 1962 a Royal Commission questioned whether the police should be responsible for investigating 
complaints against their colleagues (Royal Commission on the Police 1962). This resulted in a provision in the Police Act 1964, to allow for the investigation of complaints by a senior officer from a different police force. This system too was subjected to much criticism (Jones 1969; Justice 1970: 4-5, 7), and it was replaced by the Police Complaints Board, established by the Police Act 1976, which was the first attempt at introducing civilian oversight of police complaints. The police continued to investigate complaints as before, but the Board had limited powers of review of the process. Not surprisingly, this proved to be ineffective, and the public had little confidence in its ability to perform an oversight function (Lewis 1999: 66).

This loss of confidence was partly a result of greater social awareness during the 1970s and 1980s about the injustices perpetrated upon minority groups by the state in general and the police in particular (Lewis 1999: 54). The Brixton riots in 1981, and the subsequent inquiry into them by Lord Scarman (1981) eventually led to the Board's demise. The inquiry report recommended radical reform of the system, in order to restore public confidence in it. Two models were proposed. The first involved independent investigation for all complaints against the police. The second provided for lay supervision for serious complaints. It was the latter model that was adopted for the Police Complaints Authority, which replaced the Police Complaints Board in 1984.

Although undoubtedly an improvement on its predecessor, the Police Complaints Authority was also subject to criticism, ${ }^{1}$ and suggestions were made for reform of the system from a number of quarters: the Police Complaints Authority itself, ${ }^{2}$ Liberty (Harrison and Cunneen 2000) and the Macpherson Report (1999). The Macpherson report in particular, which investigated the conduct of the police in relation to the

\footnotetext{
${ }^{1}$ See "Foreword” by the Chair in PCA 2000. See also KPMG (2000).

${ }^{2}$ See Home Affairs Select Committee 1998.
} 
death of Stephen Lawrence, was very critical of the Police Complaints Authority’s reliance on police investigators, noting that the investigation of police officers by their own or another police service "is widely regarded as unjust, and does not inspire confidence” (Macpherson 1999: 333). Thus, by the end of the 1990s, “after a series of scandals and mounting public criticism” it was clear that the police complaints system was ready for fundamental reform (McLaughlin and Johansen 2002: 651).

\section{The Independent Police Complaints Commission}

The new system for dealing with complaints against the police in England and Wales, the Independent Police Complaints Commission (IPCC), was introduced on 1 April 2004, as a result of the Police Reform Act 2002. It is bases on proposals (see Home Office 2000), published after the Home Office appointed management consultants to examine the process of investigation into police complaints (KPMG 2000). The IPCC is a non-departmental government body, consisting of a chair and commissioners, who form its governing body and set its policy. The chair is appointed by the Queen, for five years, with the possibility of re-appointment for a second term. The commissioners are appointed by the Home Secretary for a five year term.

The IPCC's role is to ensure that its arrangements for handling complaints are efficient, effective, and “contain and manifest an appropriate degree of independence”, and to establish and maintain public confidence in the system (Police Reform Act 2002, section 10). Its remit is to investigate complaints and conduct matters in relation to police officers, police civilian staff and special constables. It cannot investigate complaints in relation to the direction and control of the police service and force policy. 
The IPCC has four procedures available to it for dealing with complaints: investigation by the police; investigation by the police supervised by the IPCC; investigation by the police managed by the IPCC; investigation by the IPCC. The first two procedures are no different to those previously operated by the Police Complaints Authority. "Managed” investigations, a new procedure, is similar to supervised investigations, but with more direct control by the IPCC, involving day-to-day direction and control of the officers appointed to investigate. "Independent” investigation is the other new process. Unlike the Police Complaints Authority, the IPCC will be able to employ its own investigators in order to conduct independent investigation of complaints. These investigators will have the same powers of seizure and questionning as the police in order to conduct the investigation.

Police forces have a duty to co-operate with the IPCC’s investigation, and have an obligation to provide access to documentation and other material and access to police premises. Chief police officers are responsible for obtaining and preserving evidence in cases involving officers under their direction and control. In addition to the powers available for conducting investigations, the IPCC also has powers to access police records, premises and documents in order to examine the efficiency and effectiveness of the arrangements for handling complaints within the police force.

The remedies available to the IPCC after an investigation has been conducted include directing the disclosure of specific information and re-investigation, and making recommendations and issuing directions on disciplinary action. Where the IPCC directs a police force to bring disciplinary charges, it can present cases against police officers at misconduct hearings. The police have a duty to comply with the recommendations and directions. The IPCC has no power to prosecute officers where 
there is evidence of criminal conduct, that function remaining with the Crown Prosecution Service.

Complaints can be made by the direct victims of the relevant conduct, those adversely affected by it, witnesses to it, or those acting on behalf of someone in these categories. The police retain the primary responsibility for recording complaints under the new system, although this can be regulated by the IPCC, which can give guidance on the procedures to be followed (Ormerod and Roberts 2003: 150). Unlike the previous system, reasons must be given if the police refuse to record a complaint, and the complainant has a right of appeal to the IPCC if the complaint is not recorded. The police must record conduct matters which have resulted in death or serious injury, and there is provision in the legislation for the Secretary of State to make regulations specifying other areas where there is to be mandatory recording. Cases where civil proceedings appear to disclose a conduct matter must also be recorded. The police must refer death or serious injury matters to the IPCC, ${ }^{3}$ and can voluntarily refer other complaints. In addition, the IPCC can require a complaint to be referred to it.

There is also provision for complaints to be resolved informally by the police, which will be known as “local resolution”. This can be used with complainant's written consent, and where the conduct, if proved, would not justify bringing criminal or disciplinary proceedings. It can also be used, with the IPCC’s approval, where it would not be practicable to bring criminal proceedings which would be likely to result in a conviction, or disciplinary proceedings that would lead to serious penalties. Importantly, the use of local resolution procedures will be monitored by the IPCC.

\section{Evaluation}

\footnotetext{
${ }^{3}$ They will also have to refer those matters specified in regulations made by the Secretary of State.
} 
It is too early to evaluate the operation of the new system, but there are a number of problems with the model adopted, particularly in relation to its independence and the ability of the IPCC to exercise control of the process. The major criticism of the previous system was its lack of independence. Although the Police Complaints Authority was in fact independent of the police, the complaints system as a whole did not possess sufficient actual ${ }^{4}$ and perceived ${ }^{5}$ independence. It is reasonably clear that only a system which is wholly independent of the police service, the civilian control model (Prenzler and Ronken 2001), can secure the confidence, not only of the public, but also the rank and file of police (Reiner 1992: 236; Waters and Brown 2000: 633; Police Federation 1997; KPMG 2000: 42).

The new system, with a new name designed to reinforce its independence from the police, does not appear to be so sufficiently different from its predecessor to be convincing as a wholly independent system. Although there is the possibility of a body independent of the police conducting its own investigations into police conduct, there is no statutory requirement to do so. The IPCC will be limited by its resources in the number of investigations it carries out, resulting in few complaints being independently investigated, ${ }^{6}$ with the vast majority of investigations continuing to be investigated by the police. Thus, if most investigations are, by force of circumstances, conducted internally, the new powers could prove to be "illusory and ineffective” (Cunneen and Harrison 2001: 8), with the system substantially replicating its predecessor, and thus unlikely to satisfy its "most ardent critics” (Ormerod and Roberts 2003: 147).

\footnotetext{
${ }^{4}$ The European Court of Human Rights found that the police complaints process did not meet the requisite standards of independence to constitute sufficient protection against the abuse of authority (Sultan Khan v UK (2001) 31 EHRR 45; (2000) 8 BHRC; [2000] CrimLR 684).

${ }^{5}$ Empirical research conducted in 1996-97 on behalf of the police in England and Wales noted a perceived lack of objectivity and independence and concern about the police investigating themselves (Waters and Brown 2000; Strudwick 2003: 35).
} 
There is also a problem with the Home Secretary's dual policing and complaints responsibilities, which may compromise the independence of the IPCC (Smith 2002). The fact that the Home Secretary has control of the appointment and dismissal of the commissioners, has led to the suggestion that the IPCC may be little more than "the latest Home Office controlled 'puppet on a string'” (McLaughlin and Johansen 2002: 635).

Thirdly, although there is provision for complaints to be made directly to the IPCC, access to the system will still largely be in the control of the police. This is a far cry from the civilian control model outlined by Prenzler and Ronken (2001: 172), which involves a complaint being initially assessed by an external agency, to identify whether there should be an investigation, mediation, or referral to another agency. The police are very much in charge of the process, with duties to keep complainants informed of the progress and outcome of the investigation.

The enhanced role of informal resolution could also be problematic. This is now known as "local resolution”, a change that emphasises that it is an official procedure (Reid 2002: 191) for resolving minor complaints. The intention of local resolution is to create a climate of conciliation (Zander 2002), to address poor performance (McLaughlin and Johansen 2002: 641), and to bring to police complaints the benefits of restorative justice. ${ }^{7}$ Such an approach may make police officers more accountable for their actions, in so far as they will have to accept responsibility in relation to the victim, and it may help to maintain public confidence by providing a pragmatic response to complaints that would be unlikely to succeed in formal proceedings (see Ormerod and Roberts 2003: 152). However, there is a danger that it may be perceived as “less procedurally legitimate and less just than formal investigation”, particularly

\footnotetext{
${ }^{6}$ KPMG (2000: 50) envisaged only about 1000 cases being independently investigated.
} 
for “disenfranchised communities and discriminated against social groups”

(McLaughlin and Johansen 2002: 651). Its very informality could lead to mistrust of what might be perceived as an internal system that fails to treat complaints seriously. Another area that may prove problematic is in relation to the investigators appointed by the IPCC. These investigators can be, or can have been, serving police officers, and this may undermine the perception of independence and thus public confidence in the system. The Home Secretary has to approve the arrangements the IPCC makes with police forces for secondments of officers. While this may provide a mechanism for restricting the numbers of serving police officers in the IPCC, it also raises questions about the independence of the system, as the Home Secretary will be able to exert "considerable influence over the effective operation of the system" if approval for the recruitment of adequate numbers of police investigators is not given (Ormerod and Roberts 2003: 153). Having said that, a sufficient number of non-police investigators should be recruited, in order to maintain public confidence.

Given the problems outlined, why was this system adopted, in preference one based on a fully-fledged civilian control model? The reasons appear to be based on cost and effectiveness. There was apparently agreement with the government’s view “that it would not be practicable or cost-effective" for the IPCC to investigate all complaints (Reid 2002: 191; see also KPMG 2000: 44), echoing the Police Complaints Authority's view that “substantial resources” would be needed (PCA 1994: 15) unless civilian investigations were reserved for the most serious complaints and conduct matters, and those of the highest public interest. This argument ignores the fact that external investigation "primarily involves a shift in resources from one agency to

\footnotetext{
${ }^{7}$ Restorative justice measures and mediation schemes have been shown to have high levels of complainant satisfaction (Dobry 2001).
} 
another rather than an additional financial cost on government” (Prenzler and Ronken 2001: 169). ${ }^{8}$

There was also the issue of the need for skilled civilian investigation staff, who would "need in-depth training in police procedures and systems", and who, moreover, "might find it more difficult to secure the co-operation of police officers in carrying out their investigations” (PCA 1994: 15). There is no evidence to suggest that nonpolice personnel cannot acquire the necessary investigation skills. Moreover, independent investigations are to be conducted in serious cases, where presumably the co-operation of police officers will need to be secured. A strong civilian control system can also gain the confidence of the police, as an impartial system will vindicate the innocent.

The vital question is whether the IPCC will restore public trust and confidence in the police after the shortcomings in the complaints process identified by MacPherson (1999). It may be that this reform is too little and too late, and the justifications for the model adopted in England and Wales begin to look a bit hollow now that it has been demonstrated what can be achieved in Northern Ireland by the introduction of a system that is modelled on civilian control.

\section{NORTHERN IRELAND: THE POLICE OMBUDSMAN}

In Northern Ireland, the model adopted for dealing with police complaints involves a completely independent system of investigation, truly representative of the civilian control model. This is the Police Ombudsman for Northern Ireland (PONI), described by the present post-holder as "probably the most advanced model of police oversight

\footnotetext{
${ }^{8}$ It has been estimated that it would cost in the region of $£ 80$ million a year to reproduce the Northern Ireland model in England and Wales. While this appears a large sum of money, it may be more appropriate to consider the cost in terms of a percentage of the overall policing budget.
} 
in the world” (O’Loan 2000). ${ }^{9}$ As the circumstances in Northern Ireland are exceptional in terms of policing within the UK, some background to the establishment of the present system is needed.

\section{Context}

Before the office of the PONI was established in 2000, police complaints in Northern Ireland were dealt by the Independent Commission for Police Complaints, a system similar to the Police Complaints Authority. Under that system, officers of the Royal Ulster Constabulary investigated complaints against fellow officers under the direction of the Independent Commission for Police Complaints. Its replacement by the PONI followed the review of the system of police complaints (Hayes 1997) and the more general review of policing in Northern Ireland (Patten 1999).

The Hayes review, conducted by the former Northern Ireland Ombudsman, recommended that the Independent Commission for Police Complaints be replaced by an independent system based around an ombudsman. The Patten Commission was initiated under the terms of the 1998 Good Friday Agreement to investigate future policing structures and arrangements for Northern Ireland. Reform of the police service emerged as a central plank of the peace process, an essential part of the peace dividend (see Ellison and Mulchay 2001: 252). As a result, there were changes to the Royal Ulster Constabulary, renamed the Police Service of Northern Ireland, which included equal recruitment across the sectarian divide. A Policing Board replaced the Police Authority for Northern Ireland, with responsibilities for setting the policing plan, allocating the budget and monitoring performance (Ellison and Mulcahy 2001:

\footnotetext{
${ }^{9}$ In Queensland and New South Wales in Australia, New Zealand and South Africa there are similar institutions to that in Northern Ireland, but none is equal in terms of its independence and statutory powers (O’Loan 2002: 13).
} 
253-254). The Patten report also suggested that a Police Ombudsman would provide the key to the effectiveness of the new policing arrangements for Northern Ireland.

These new arrangements need to be set in context. Northern Ireland has a population of some 1.5 million, and an armed police force of around 13,000. During the past 30 years, there has been a total of over 3,300 deaths in the province, around 300 of which were police officers. Over 43,000 people have been injured, over a fifth of these being police officers. The population was deeply split on religious grounds in its perception of and support for the police. The work of the PONI has to be seen within this scenario.

\section{Police Ombudsman for Northern Ireland}

The PONI, established by the Police Act (Northern Ireland) 1998, began work in October 2000. The stated role of the office is to ensure the efficiency, effectiveness and independence of the police complaints system and to secure the confidence of the public and members of the police force in the system. The PONI's remit is the investigation of complaints about the conduct of police officers, including allegations of criminal conduct. Matters to do with the direction and control of the police are outside remit, although these complaints must be analysed and referred to the police. The PONI can investigate, informally resolve, or seek mediation of a complaint, and is also required to supply statistical information on complaints, and to monitor trends and patterns in complaints. The PONI can make recommendations for improving practice, and can publish special reports.

As noted, the PONI system is based on the civilian control model, and thus, very importantly, there is the power to investigate all complaints against the police. The PONI has her own investigation staff for conducting investigations, with wide ranging 
powers. The police can be compelled to supply material to the investigators, and they are under a duty to preserve evidence and to facilitate the work of the office. It is a criminal offence to restrict, impede or obstruct the PONI's investigation.

As in England and Wales, the PONI cannot prosecute police officers, and where an investigation reveals that a criminal offence may have been committed, this is referred to the Director of Public Prosecutions for Northern Ireland. The PONI can however make recommendations about disciplinary matters, and has the power to direct that disciplinary proceedings be brought. Recommendation for compensation can also be made, payment of which does not affect other legal rights a complainant may have. Complaints may be resolved informally, with the complainant's consent, where appropriate. This procedure is used for minor complaints, including allegations of failure of duty and incivility, where the conduct alleged, if proved, would not justify criminal proceedings. Informal resolution is conducted by the police, but on completion the related papers are forwarded to the PONI, in order to ensure that all the elements of the complaint have been dealt with, the process has been properly handled, and the matter conducted to the satisfaction of the parties involved.

The PONI can be accessed directly by or on behalf of any member of the public, by letter, email, fax, telephone and personal callers, and the office is accessible 24 hours a day, seven days a week. In certain circumstances, the PONI’s staff will visit complainants at home or attend at an agreed venue. Where complaints are made directly to the police, there is a duty to refer them to the PONI, and the PONI can also investigate on her own motion in the absence of a complaint, where a criminal or disciplinary offence may have been committed. The PONI must investigate cases of death or serious injury. 


\section{Evaluation}

The most striking aspect of the system for dealing with complaints against the police in Northern Ireland is that the process is completely independent of the police. The PONI has responsibility both for processing and conducting independent investigations, and handles the whole range of complaints, from allegations of police incivility to those involving very serious criminal offences. Investigators from the PONI's office collect evidence, visits scenes of crime, and conduct investigations. Only minor complaints, which can be resolved informally, are forwarded to the police for resolution, and even these remain within the PONI's control, as the PONI checks that the process has been conducted to the satisfaction of the parties involved.

Not only is the office independent, but also it is perceived to be so (Hamilton et al 2003: 12; PONI 2003: PONI 2002), with both communities in Northern Ireland generally viewing the PONI in a positive way (Hamilton et al 2003: 7). The independence of the system is reinforced by the fact that the PONI has control of the process from the initial complaint. All complaints are made directly to the PONI, or are referred to the PONI by the police. This accessibility is facilitated by the high profile adopted by the office, and the efforts made to publicise its work. Resources are important to the effectiveness of the office, as without proper funding the office would not be able to carry out its remit, no matter what powers it is given. ${ }^{10}$ It appears that the PONI has been given enough resources to enable it to carry out its investigations effectively, with a budget in excess of $£ 6$ million a year (PONI 2003: 75), ${ }^{11}$ representing about $1 \%$ of the policing budget.

\footnotetext{
${ }^{10}$ The South African Independent Complaints Directorate has similar powers to the Police Ombudsman, but is less effective because it has a small budget and is understaffed (see Manby 2000: 218).

${ }^{11}$ In comparison, the Police Complaints Authority had a budget of around $£ 4.5$ million, and it has been estimated that the budget for the IPCC will be around $£ 14$ million.
} 
In the short time since its inception, the PONI has demonstrated its ability to conduct thorough investigations, some in very high profile cases. ${ }^{12}$ The PONI has demonstrated that a strong civilian control model can work, and there is growing confidence in the system, even within the police service. It is true that the office was established in the situation of the unusual policing context of Northern Ireland, and as part of the process of bringing peace to that troubled province. Unlike England and Wales, it was part of a root and branch change to the policing structure, rather than a gradualist, incremental approach. Despite these special circumstances, the success of the office can serve as a model for other jurisdictions.

\section{SCOTLAND}

Scotland has no equivalent body to the IPCC or PONI, complaints being dealt with primarily by police forces, although the Scottish Executive is considering proposals to reform the existing arrangements (Scottish Executive 2001). Before considering these proposals, the existing system in Scotland needs to be examined, together with an outline of the context of Scottish policing.

\section{Context}

As in the rest of the UK, Scotland has a tripartite system for the control of the police. However, there are some differences, resulting from devolution and changes to local government in Scotland, which has effected the governance of the police (see Donnelly and Scott 2002a). At the local level, the introduction of single-tier local authorities in the 1990s resulted in the creation of local police boards, which are more diffuse in their composition than previously. At central government level, policing has

\footnotetext{
${ }^{12}$ For example, the report into the Omagh bombing (see PONI 2001).
} 
become a devolved matter, and thus the responsibility of Scottish rather than UK ministers. Scotland has a Justice Minister, whose responsibilities include the police, and Scottish Ministers approve the appointment of chief constables. The Scottish Executive has a number of Parliamentary committees, including two Justice Committees, which not only shadow the work of a particular ministerial department, but also play a part in initiating legislation, as well as scrutinising it, and conducting inquiries into subjects of their own choice.

These factors have led to a concern that the Scottish Parliament may "suck up the powers of local government itself” in relation to policing matters (McFadden and Lazarowicz 1999: 79), and maybe even result in a single national force. Added to this is the fact that the roles and responsibilities of police authorities and their respective chief constables are not laid out in statute, as they are in England and Wales. All this has resulted in some ambivalence about the traditional tripartite system of policing and confusion about the respective roles of the Parliament and Executive, the Inspectorate, and the audit machinery (see Donnelly and Scott 2002a). The tripartite system is thus very different to the one in England and Wales. It is against this background that the reform of the police complaints process in Scotland is taking place.

\section{Police Complaints in Scotland}

There are a number of bodies with responsibilities in relation to complaints against the police in Scotland. Police authorities have responsibilities for monitoring the process of complaints, and also for dealing with complaints against chief officers. The Chief Inspector of Constabulary for Scotland has to provide an annual report to Scottish Ministers on the state and efficiency of the police forces in Scotland, using 
inspections of individual police forces as a basis for the report. Part of the inspection process involves examining the handling of public complaints against the police (see generally Donnelly and Scott 2002b).

In the case of allegations of criminal acts against the police, it is important to note that there are different prosecution procedures in Scotland to the rest of the UK.

Responsibility for the investigation and prosecution of crime rests with the Crown, the Crown Office, and Procurator Fiscal Service. The latter is headed by the Lord Advocate and is independent of the judiciary and the police. Although the police normally gather evidence and undertake enquiries on behalf of the procurator fiscal, “in practice the Fiscal retains primacy at all times” (HMCICS 2000: 17), and it is even possible for investigation and prosecution decisions to be undertaken by the Crown with minimal or even no involvement on the part of the police (HMICS 2000: 18). Thus, complaints alleging criminal conduct by police officers are investigated by the Regional Procurator Fiscal for the relevant force area, on behalf of the Lord Advocate.

Complaints about police misconduct are investigated by the officer's force either at local level or by the Deputy Chief Constable. Police authorities are responsible for dealing with complaints against chief officers. For both criminal and conduct complaints, the Regional Procurator Fiscal or police force can request the appointment of investigating officers from another force in order to carry out the investigation.

General oversight of the complaints process is provided by Her Majesty’s Inspectorate of Constabulary, which can be requested by a dissatisfied complainant to review the way a complaint was handled. After such a review, a report on the findings is sent to the complainant, with a copy to the chief constable and the officer who was 
the subject of the complaint. The Inspectorate cannot investigate any formal action taken against the police officer, its function being to examine how the complaint was originally investigated.

\section{Reform Proposals}

In 2001, the Scottish Executive published proposals for reform of the system, and conducted a consultation process (Scottish Executive 2001). The proposals do not envisage any changes to the process of investigation for criminal allegations, which will continue as before. For other complaints it is proposed that a new body should be established, leaving the police authorities and Inspectorate to their efficiency and management roles (Scottish Executive 2001: paras 41, 43). Two systems are suggested in the consultation, the first, an "ombudsman”, with a wider role than the Inspectorate, but still with an essentially supervisory role, having power to order and oversee new investigations, and to conduct random sampling of the complaints systems operated by the police (Scottish Executive 2001: para 47). The second is an independent complaints body, with responsibility for handling all complaints at first instance, with complaints being made directly or referred to it (Scottish Executive 2001: para 48).

Four models are discussed for the new body. In the first, complaints will be referred to the police for investigation, with the new body having power to undertake a supervisory role in connection with the police investigation. The second model will involve less serious complaints being referred to the police; the independent body supervising the investigation of more serious cases; and criminal allegations being referred to the Regional Procurator Fiscal. The third option is for the new body to supervise investigations into all complaints. Finally, the most radical option is for the 
body to undertake its own investigations into serious or all complaints, using its own investigation staff, as in Northern Ireland.

There is as yet no indication of which model will be adopted, and there have been no further announcements in relation to this review process to date.

\section{Evaluation}

In Scotland, there are no systems of independent investigation comparable to the rest of the UK. The system for dealing with criminal allegations is independent of the police, but where the complaint does not allege criminal conduct, the police are left to investigate the matter themselves. The only independent element in this process is provided in the review of the system by the police authorities and Inspectorate. There is no independent element in the investigation process itself.

Despite the fact that there has been no major crisis in police complaints in Scotland, the existing internal system is no longer seen as appropriate, and the proposals for reform envisage a more independent model involving some element of civilian input. Whether this becomes a civilian review model or a civilian control one remains to be seen.

\section{CONCLUSION}

There has been a "growing momentum" for the independent investigation of complaints against the police (Smith 2001: 372), and the "legislative tendency" has reflected a trend towards this (Smith 2000: 6). To some extent this reflects a general trend to external review that is occurring across the professions and public sector, ${ }^{13}$ but it is fuelled by various crises in relation to complaints and policing generally. The

\footnotetext{
${ }^{13}$ See Seneviratne (2000) in relation to the legal profession, for example.
} 
fact is that it is no longer considered acceptable for complaints to be dealt with by the police themselves, and the investigation of police officers by their own or another police force "is widely regarded as unjust, and does not inspire public confidence" (Macpherson Report 1999: recommendation 58).

Public confidence in the police service is essential if there is to be respect for the rule of law. The effectiveness of the police service is closely linked with their moral authority, and depends to a large extent on community support (Goldsmith 1995: 120). Moreover, the community has a right to be involved in keeping the coercive arm of the state, the police, publicly accountable for its actions. Models of police complaints mechanisms, which are controlled entirely by the police with no external input, are no longer seen as appropriate, and no longer command public support. Civilian oversight bodies that are confined to asking the police questions about a police investigation into police misconduct after the investigative process is complete are inadequate.

Systems for investigating police complaints in the UK have varying degrees of external involvement and oversight. Each one can to some extent be characterised in terms of Prenzler and Ronkin’s (2001) models. Scotland with little external oversight typifies the internal model; England and Wales is still largely based on civilian oversight; and it is only in Northern Ireland that there is a system conforming to the civilian control model. In Scotland, the proposals for reform do envisage a more independent system, although it is not clear what level of civilian oversight will be adopted. The Northern Ireland model is the most advanced in terms of external oversight, with the PONI, not the police, conducting investigations. The new system for England and Wales, while an improvement on its predecessor, has not followed 
the Northern Ireland model, and the police will still conduct the majority of investigations.

The system in Northern Ireland is proving to be very effective, which raises the issue of why a similar system should not be adopted in England and Wales. The IPCC is still very much a compromise model, which may prove to be as unsatisfactory as the one it replaces. It is accepted that there were particular needs in the Northern Ireland context that had to be addressed, and that the PONI was part of a process of reform to the whole policing structure there. However, that is no reason for restricting this model to Northern Ireland. The positive lessons that are emerging from Northern Ireland present very persuasive reasons for extending the model to other parts of the UK. The very success of the PONI model emphasises the inadequacies of other systems, and will present a yardstick against which the IPCC and a reformed system in Scotland, will be judged, and maybe found wanting. 


\section{REFERENCES}

Bayley, B. (1995) Getting Serious about Police Brutality. In: Stenning, C. (ed) Accountability for Criminal Justice. University of Toronto Press, Toronto.

Cunneen, M. and Harrison, J. (2001) Framework for a New System. Legal Action,6-8.

Dobry, J. (2001) Restorative Justice and Police Complaints: A Report by the Independent Police Complaints Authority. Police Complaints Authority, London

Donnelly, D. and Scott, K. (2002a) Police Accountability in Scotland: [1] The 'New' Tripartite System. Police Journal, 75, 3-12.

Donnelly, D. and Scott, K. (2002b) Police Accountability in Scotland: [2] New Accountability. Police Journal. 75, 56-66.

Ellison, G. and Mulchay, A. (2001) Policing and Social Conflict in Northern Ireland. Policing and Society, 11, 243-258.

Goldsmith, A. (1988) New Directions in Police Complaints Procedures: Some Conceptual and Comparative Departures. Police Studies, 11(1), 60-71.

Goldsmith, A. (1995) Necessary but Not Sufficient: The Role of Public Complaints Procedures in Police Accountability. In: Stenning, C. (ed) Accountability for Criminal Justice. University of Toronto Press, Toronto.

Goldsmith, A. and Lewis, C. (eds) (2000) Civilian Oversight of Policing: Governance, Democracy and Human Rights. Hart Publishing, Oxford.

Hamilton, J., Radford, K. and Jarman, N. (2003) Policing, Accountability and Young People. Institute for Conflict Research, Belfast.

Harrison, J. and Cragg, S. (1995) Police Misconduct: Legal Remedies. $3^{\text {rd }}$ edition. Legal Action Group, London.

Harrison, J. and Cunneen, M. (2000) An Independent Police Complaints Commission. Liberty, London.

Hayes, M. (1997) A Police Ombudsman for Northern Ireland? HMSO, Belfast.

Her Majesty’s Inspectorate of Constabulary (1999) Annual Report 1989/99. HMSO, London.

Her Majesty’s Inspectorate of Constabulary (2000) Annual Report 1999/2000. HMSO, London.

Her Majesty's Inspectorate of Constabulary for Scotland (2000) A Fair Cop? The Investigation of Complaints against the Police in Scotland. HMSO, Edinburgh. 
Home Affairs Select Committee (1998) Police Complaints and Disciplinary Procedures: First Report, HC 258. HMSO, London.

Home Office (2000) Complaints Against the Police - Framework for a New System. HMSO, London.

Hoyle, C. (2001) Restorative justice in the Thames valley: changes in the complaints and discipline process. Prison Service Journal, 133, 37-40.

Jones, M. (1969) The Police and the Citizen. National Council for Civil Liberties, London.

Justice (1970) Recommendations Submitted to the Police Advisory Boards' Joint Working Party on the Investigation of Complaints. Justice, London.

KPMG (2000) Feasibility of an Independent System for Investigating Complaints against the Police. Home Office: Police Research Series Paper 24. HMSO, London.

Lewis, C. (1999) Complaints Against the Police: The Politics of Reform. Hawkins Press, Sydney.

Macpherson, W. (1999) The Stephen Lawrence Inquiry: Report of an Inquiry by Sir William Macpherson of Cluny, Cm4262. HMSO, London.

Maguire, M. (1991) Complaints against the Police: The British Experience. In: Goldsmith, A. (ed) Complaints Against the Police: the Trend to External Review. Clarendon Press, Oxford.

Maguire, M. and Corbett, C. (1989) Patterns and profiles of complaints against the police. In: Morgan, R. and Smith, D. (eds) Coming to Terms with Policing.

Routledge, London.

Maguire, M. and Corbett, C. (1991) A Study of the Police Complaints System. HMSO, London.

Manby, B. (2000) The South African Independent Complaints Directorate. In: Goldsmith, A. and Lewis, C. (eds) Civilian Oversight of Policing: Governance, Democracy and Human Rights. Hart Publishing, Oxford.

McFadden, J. and Lazarowicz, M. (1999) The Scottish Parliament - An Introduction. T \& T Clark, Edinburgh.

McLaughlin, E. and Johansen, A. (2002) A force for change? The prospects for applying restorative justice to citizen complaints against the police in England and Wales. British Journal of Criminology, 42(3), 635-653.

O’Loan, N. (2000) The Police Ombudsman for Northern Ireland - An Introduction. The Ombudsman, 14 August. BIOA, London. 
Ormerod, D. and Roberts, A. (2003) The Police Reform Act 2002 - increasing centralisation, maintaining confidence and contracting out crime control. Criminal Law Review, 141-164.

Patten, C. (1999) A New Beginning: Policing in Northern Ireland, Report of the Independent Commission on Policing for Northern Ireland. HMSO, London.

Police Complaints Authority (1994) Triennial Review of the Police Complaints Authority 1991-94. HMSO, London.

Police Complaints Authority (2000) Annual Report and Accounts of the Police Complaints Authority 1999-2000. HMSO, London.

Police Federation (1997) Police Accountability (http://polfed.otg.uk/wherwes.htm).

Police Monitoring and Research Group (1987) Police Complaints: A Fresh Approach. Strategic Policy Unit, London.

Police Ombudsman for Northern Ireland (2001) A Statement by the Police Ombudsman for Northern Ireland on her investigation of matters relating to the Omagh bombing on 15 August 1998. Belfast.

Police Ombudsman for Northern Ireland (2002) Public Awareness of the Northern Ireland Police Complaints System 2002. Research Report 2/2002. Belfast.

Police Ombudsman for Northern Ireland (2003) Police Ombudsman for Northern Ireland Annual Report 2002-03. Belfast.

Prenzler, T. and Ronken, C. (2001) Models of Police Oversight: A Critique. Policing and Society, 11(3),151-180.

Punch, M. (2003) Rotten Orchards: 'Pestilence’, Police Misconduct and Systems Failure. Policing and Society, 13(2), 171-196.

Reid, K. (2002) Current developments in police accountability. Journal of Criminal Law, 66(2), 172-195.

Reiner, R. (1992) The Politics of the Police. Harvester, Hemel Hempstead.

Royal Commission on the Police (1962) Final Report, Cmnd 1728. HMSO, London.

Scarman, Lord (1981) Report on the Brixton Disorders of 10-12 April 1981, Cmnd 8427. HMSO, London.

Scottish Executive (2001) Complaints Against the Police: A Consultation Paper. HMSO, Edinburgh.

Seneviratne, M. (2000) Consumer complaints and the legal profession: making selfregulation work? International Journal of the Legal Profession, 7(1), 39-58. 
Smith, G. (2000) The police complaint process: Identifying rotten apples or satisfying grievances? Criminal Lawyer, 99, 4-6.

Smith, G. (2001) Police Complaints and Criminal Prosecutions. Modern Law Review, 64(3), 372-392.

Smith, G. (2002) The Police Complaints Commission: Independent From Whom? Criminal Justice Matters, 47, 40-41.

Smith, G. (2003) Actions for damages against the police and the attitudes of claimants. Policing and Society, 13(4), 413-422.

Smith, G. (2004) Rethinking Police Complaints. British Journal of Criminology, 44(1), 15-33.

Strudwick, K. (2003) Is independence the only answer to complainants' satisfaction of the police complaints process? A perspective from the United Kingdom. Police Practice and Research, 4(1), 35-46.

Ward, S. (2002) Is it a Fair Cop? Law Society Gazette, 99(4), 20-21.

Waters, I. and Brown, K. (2000) Police complaints and the complainants' experience. British Journal of Criminology, 40(4), 617-638.

Zander, M. (2002) The Police Reform Act 2002 - Pt 2. New Law Journal, 152, 13871388. 